\title{
ANALIZA WPLYWU PANDEMII COVID-19 \\ NA ZDAWALNOŚĆ NOTARIALNEGO EGZAMINU ZAWODOWEGO
}

\author{
Jacek Wiatrowski \\ Ph.D. in Law, Institute of Law and Administration, \\ Polonia University in Czestochowa, Poland \\ e-mail: j.wiatrowski@ap.edu.pl,orcid.org/0000-0001-7032-5036
}

\section{Karol Wiatrowski}

BSc in Economics, Faculty of Management and Social Communication, Institute of Economics, Finance and Management, Jagielonian University, Poland e-mail: karol.wiatrowski@student.uj.edu.pl,orcid.org/0000-0002-3479-9426

\section{Streszczenie}

Epidemia COVID-19 była jednym z kilku czynników, który mógł mieć wpływ na dostęp do egzaminów notarialnych w 2020 roku. Należy jednak wskazać, że wpływ ten nie miał jednostronnego charakteru. W przypadku egzaminów notarialnych rzeczona zależność miała negatywny charakter, co jest zauważalne przede wszystkim poprzez nagły spadek liczby osób, które zdecydowały się przystąpić do omawianego egzaminu w stosunku do ubiegłego roku. Spadek liczby osób, które uzyskały pozytywny wynik z rzeczonego egzaminu prawdopodobnie nie pozostawał w bezpośrednim związku z epidemią COVID-19. Należy postawić tezę, iż zdawalność egzaminu notarialnego charakteryzuje się wysokim zróżnicowaniem wyników w różnych latach. Czynnikami, które mają decydujący wpływ na osiągane przez przystępujących rezultaty, pozostają przede wszystkim trudność pytań egzaminacyjnych, czy też stopień przygotowania zdających osób.

Słowa kluczowe: notariusz, egzamin, zdawalność.

\section{DOI https://doi.org/10.23856/4328}

Profesja, notariusza powszechnie postrzegana jest jako zawód o szczególnym znaczeniu dla społeczeństwa, a także jako służba publiczna dla ochrony dóbr wyższego rzędu w szczególności ładu społecznego, praw wolności jednostki, zdrowia, życia czy mienia osobistego lub publicznego. Przestrzeganie wartości etycznych podczas wykonywania tych zawodów, zachowanie reguł staranności oraz tajemnicy zawodowej to podstawowe atrybuty tej profesji (Wiatrowski, Nowicka, 2019).

Notariusz działa jako osoba zaufania publicznego. Natomiast, notariat (Puchaty, 1974) zgodnie z definicją to - instytucja mająca na celu zapewnienie bezpieczeństwa obrotu prawnego i jego zgodności z obowiązującym prawem. Cytując literalne brzmienie art. 2 ustawy Prawo o notariacie (Ustawa z dn. 14 lutego 1991 r.) - notariusz w zakresie swoich uprawnień, o których mowa w art. 1, działa jako osoba zaufania publicznego, korzystając z ochrony przysługującej funkcjonariuszom publicznym.

Doktryna wskazuje cechy wyróżniające notariuszy od innych zawodów prawniczych, potwierdzające status notariusza jako osoby zaufania publicznego. Dlatego też, należy podkreślić i przytoczyć wielość wiodących genotypów symptomatycznych dla profesji notarialnej. Jako podstawowy i priorytetowy zaliczyć należy nieskazitelny charakter osoby wstępującej w szranki korporacji notarialnej. Kolejnym elementem świadczącym o powadze wykonywanej funkcji jest używanie pieczęci urzędowej z wizerunkiem orła. Ważny do wyartykułowania 
pozostaje również fakt, iż wszystkie wykonywane czynności notarialne mają charakter dokumentu urzędowego. Również do wiodących charakterystycznych cech tego zawodu winno się zaliczyć obowiązek tajemnicy zawodowej. Zachowania w tajemnicy okoliczności sprawy oraz faktu, iż powinność ta ustaje tylko wtedy, gdy notariusz składa zeznanie jako świadek przed sądem za wyjątkiem ujawnienie tajemnicy, która zagraża dobru państwa albo ważnemu interesowi prywatnemu.

Należy mieć na uwadze, iż samorząd zawodowy o którym mowa w art. 17 ust. 1 Konstytucji RP (Konstytucja Rzeczpospolitej Polskiej z dnia 2 kwietnia 1997) wykonuje swoje zadania wyłącznie w granicach interesu publicznego. Innymi słowy oznacza to w szczególności zakaz nadużywania swojej pozycji. Ma to przede wszystkim na celu przeciwdziałanie nadmiernemu ograniczaniu sposobności w możliwości nabycia danych uprawnień zawodowych (Wiatrowski, J. Wiatrowski, B. Wanot, 2020). Jak podkreśla P. Sarnecki w komentarzu odnoszącym się do art. 17 Konstytucji RP - „Podstawa włączenia określonego zawodu do kategorii zawodu zaufania publicznego powinno być zawsze uznanie, że natożenie owych ograniczeń nie następuje $w$ celu stworzenia określonej grupie zawodowej przywilejów, lecz ma służyć interesowi publicznemu, a zakres ograniczeń winien być odpowiedni do ochrony tego interesu. Konstytucja wymaga obdarzenia szczególnym statusem osoby wykonujace zawody zaufania publicznego, a jednocześnie wymaga, aby regulacja prawna sposobu ich wykonywania potwierdzała $i$ instytucjonalizowała zaufanie do nich". (Sarnecki, 2005)

Notariusza powołuje i wyznacza siedzibę jego kancelarii Minister Sprawiedliwości, na wniosek osoby zainteresowanej, po zasięgnięciu opinii Rady właściwej Izby Notarialnej.

Zgodnie z ustawą prawo o notariacie, Notariuszem może być powołany ten, kto:

1) posiada obywatelstwo polskie, obywatelstwo innego państwa członkowskiego Unii Europejskiej, państwa członkowskiego Europejskiego Porozumienia o Wolnym Handlu (EFTA) - strony umowy o Europejskim Obszarze Gospodarczym lub Konfederacji Szwajcarskiej, albo obywatelstwo innego państwa, jeżeli na podstawie przepisów prawa Unii Europejskiej przysługuje mu prawo podjęcia zatrudnienia lub samozatrudnienia na terytorium Rzeczypospolitej Polskiej na zasadach określonych w tych przepisach;

2) korzysta w pełni z praw publicznych i ma pełną zdolność do czynności prawnych;

3) jest nieskazitelnego charakteru i daje rękojmię prawidłowego wykonywania zawodu notariusza;

4) ukończył wyższe studia prawnicze w Rzeczypospolitej Polskiej i uzyskał tytuł magistra lub zagraniczne studia prawnicze uznane w Rzeczypospolitej Polskiej;

5) odbył aplikację notarialną w Rzeczypospolitej Polskiej;

6) złożył egzamin notarialny w Rzeczypospolitej Polskiej;

7) ukończył 26 lat.

Dodatkowo, z treści rzeczonej ustawy wynika, iż wymagania odbycia aplikacji notarialnej w Rzeczypospolitej Polskiej i złożenia egzaminu notarialnego, nie dotyczą osób, które:

1) uzyskały tytuł naukowy profesora lub stopień naukowy doktora habilitowanego nauk prawnych;

2) zajmowały stanowisko sędziego lub prokuratora;

3) wykonywały zawód adwokata lub radcy prawnego przez okres co najmniej 3 lat;

4) zajmowały stanowisko radcy lub starszego radcy Prokuratorii Generalnej Skarbu Państwa przez okres co najmniej 3 lat.

Również, bez odbycia aplikacji notarialnej do egzaminu notarialnego mogą z kolei przystąpić osoby, które w Rzeczypospolitej Polskiej:

1) posiadają stopień naukowy doktora nauk prawnych; 
2) przez okres co najmniej 4 lat w okresie nie dłuższym niż 6 lat przed złożeniem wniosku o dopuszczenie do egzaminu były zatrudnione na stanowisku referendarza sądowego, starszego referendarza sądowego, asystenta prokuratora, asystenta sędziego lub były zatrudnione w Sądzie Najwyższym lub w Trybunale Konstytucyjnym i wykonywały zadania odpowiadające czynnościom asystenta sędziego;

3) po ukończeniu wyższych studiów prawniczych przez okres co najmniej 4 lat w okresie nie dłuższym niż 6 lat przed złożeniem wniosku o dopuszczenie do egzaminu wykonywały na podstawie umowy o pracę lub umowy cywilnoprawnej wymagające wiedzy prawniczej czynności bezpośrednio związane z czynnościami wykonywanymi przez notariusza w kancelarii notarialnej;

4) po ukończeniu wyższych studiów prawniczych przez okres co najmniej 4 lat w okresie nie dłuższym niż 6 lat przed złożeniem wniosku o dopuszczenie do egzaminu były zatrudnione w urzędach organów władzy publicznej i wykonywały wymagające wiedzy prawniczej czynności bezpośrednio związane ze świadczeniem pomocy prawnej na rzecz tych urzędów;

5) po ukończeniu aplikacji legislacyjnej przez okres co najmniej 4 lat w okresie nie dłuższym niż 6 lat przed złożeniem wniosku o dopuszczenie do egzaminu były zatrudnione w urzędach organów władzy publicznej lub w państwowych jednostkach organizacyjnych i wykonywały wymagające wiedzy prawniczej czynności bezpośrednio związane z tworzeniem projektów ustaw, rozporządzeń lub aktów prawa miejscowego;

6) zajmują stanowisko radcy lub starszego radcy Prokuratorii Generalnej Skarbu Państwa;

7) zdały egzamin sędziowski, prokuratorski, adwokacki, radcowski lub komorniczy;

jak również osoby, które przez okres co najmniej 4 lat w okresie nie dłuższym niż 6 lat przed złożeniem wniosku o dopuszczenie do egzaminu były zatrudnione w międzynarodowym organie sądowym, w szczególności w Trybunale Sprawiedliwości Unii Europejskiej lub Europejskim Trybunale Praw Człowieka i wykonywały zadania odpowiadające czynnościom asystenta sędziego, przy czym osoby te muszą także spełniać wskazane powyżej w punktach: 1-4 i 7 wymagania przewidziane dla powołania na notariusza.

Relewantnym pozostaje, iż najczęstszej wybieraną przez kandydatów na notariuszy drogą dojścia do tego zawodu, jest rozwiązanie polegające na odbyciu aplikacji notarialnej i złożenie egzaminu notarialnego.

Zgodnie z cytowana ustawą prawo o notariacie, do egzaminu notarialnego może przystąpić osoba, która ukończyła aplikację notarialną w Rzeczypospolitej Polskiej i otrzymała zaświadczenie o jej odbyciu.

Natomiast, bez odbycia aplikacji notarialnej do egzaminu notarialnego mogą przystąpić osoby, które:

1) posiadają stopień naukowy doktora nauk prawnych;

2) przez okres co najmniej 4 lat w okresie nie dłuższym niż 6 lat przed złożeniem wniosku o dopuszczenie do egzaminu były zatrudnione na stanowisku referendarza sądowego, starszego referendarza sądowego, asystenta prokuratora, asystenta sędziego lub były zatrudnione w Sądzie Najwyższym lub w Trybunale Konstytucyjnym i wykonywały zadania odpowiadające czynnościom asystenta sędziego;

3) po ukończeniu wyższych studiów prawniczych przez okres co najmniej 4 lat w okresie nie dłuższym niż 6 lat przed złożeniem wniosku o dopuszczenie do egzaminu wykonywały na podstawie umowy o pracę lub umowy cywilnoprawnej wymagające wiedzy prawniczej czynności bezpośrednio związane z czynnościami wykonywanymi przez notariusza w kancelarii notarialnej;

4) po ukończeniu wyższych studiów prawniczych przez okres co najmniej 4 lat w okresie nie dłuższym niż 6 lat przed złożeniem wniosku o dopuszczenie do egzaminu były zatrudnione 
w urzędach organów władzy publicznej i wykonywały wymagające wiedzy prawniczej czynności bezpośrednio związane ze świadczeniem pomocy prawnej na rzecz tych urzędów;

5) po ukończeniu aplikacji legislacyjnej przez okres co najmniej 4 lat w okresie nie dłuższym niż 6 lat przed złożeniem wniosku o dopuszczenie do egzaminu były zatrudnione w urzędach organów władzy publicznej lub w państwowych jednostkach organizacyjnych i wykonywały wymagające wiedzy prawniczej czynności bezpośrednio związane z tworzeniem projektów ustaw, rozporządzeń lub aktów prawa miejscowego;

6) zajmują stanowisko radcy lub starszego radcy Prokuratorii Generalnej Skarbu Państwa;

7) zdały egzamin sędziowski, prokuratorski, adwokacki, radcowski lub komorniczy;

jak również osoby, które przez okres co najmniej 4 lat w okresie nie dłuższym niż 6 lat przed złożeniem wniosku o dopuszczenie do egzaminu były zatrudnione w międzynarodowym organie sądowym, w szczególności w Trybunale Sprawiedliwości Unii Europejskiej lub Europejskim Trybunale Praw Człowieka i wykonywały zadania odpowiadające czynnościom asystenta sędziego, przy czym osoby te muszą także:

1) posiadać obywatelstwo polskie, obywatelstwo innego państwa członkowskiego Unii Europejskiej, państwa członkowskiego Europejskiego Porozumienia o Wolnym Handlu (EFTA) - strony umowy o Europejskim Obszarze Gospodarczym lub Konfederacji Szwajcarskiej, albo obywatelstwo innego państwa, jeżeli na podstawie przepisów prawa Unii Europejskiej przysługuje im prawo podjęcia zatrudnienia lub samozatrudnienia na terytorium Rzeczypospolitej Polskiej na zasadach określonych w tych przepisach;

2) korzystać w pełni z praw publicznych i mieć pełną zdolność do czynności prawnych;

3)być nieskazitelnego charakteru i odpowiednio dawać rękojmię prawidłowego wykonywania zawodu notariusza;

4) mieć ukończone wyższe studia prawnicze w Rzeczypospolitej Polskiej i uzyskany tytuł magistra lub zagraniczne studia prawnicze uznane w Rzeczypospolitej Polskiej;

5) mieć ukończone 26 lat.

Istotnym w rzeczonym opracowaniu pozostaje wyartykułowanie trybu i formy egzaminu zawodowego i egzegeza jego zdawalności. Mianowicie, egzamin notarialny przeprowadza się raz w roku w terminie wyznaczonym przez Ministra Sprawiedliwości. Minister Sprawiedliwości zamieszcza w Biuletynie Informacji Publicznej, nie później niż na 90 dni przed terminem egzaminu notarialnego, ogłoszenie o egzaminie notarialnym, w którym podaje w szczególności: termin złożenia wniosku o dopuszczenie do egzaminu notarialnego, adres siedziby komisji kwalifikacyjnej, termin przeprowadzenia przez komisję kwalifikacyjną każdej części egzaminu notarialnego i wysokość opłaty za egzamin notarialny.

Egzamin notarialny polega na sprawdzeniu przygotowania prawniczego osoby przystępującej do egzaminu notarialnego do samodzielnego i należytego wykonywania zawodu notariusza. Składa się z trzech części pisemnych. Pierwsza i druga część egzaminu notarialnego polegają na opracowaniu projektów aktów notarialnych na podstawie opisanych przypadków. Trzecia część egzaminu notarialnego polega na opracowaniu projektu odmowy dokonania czynności notarialnej albo uzasadnienia jej dopuszczalności albo na opracowaniu projektu czynności notarialnej innej niż akt notarialny.

Ważnym jest, iż pozytywny wynik z egzaminu notarialnego otrzymuje zdający, który z każdej części egzaminu notarialnego otrzymał ocenę pozytywną. W przypadku nieuzyskania pozytywnego wyniku z egzaminu notarialnego, zdający może przystępować do kolejnych egzaminów notarialnych, z tym, że egzamin ten zdaje w całości (Ustawa z dn. 14 lutego 1991 r.).

Zważywszy na przedstawiony schemat dostępności do wykonywania zawodu notariusza, zasadniczym celem badawczym rzeczonego opracowania pozostaje, analiza wpływu 
pandemii Covid -19 na zdawalność egzaminu zawodowego notariusza. W tym celu poddano szczegółowej analizy wyniki uzyskane z egzaminu notarialnego kończącego okres aplikacji i umożliwiającego wykonywaniu profesji rejenta. W tym celu zostaną przedstawione dane dotyczące liczby osób, które zdecydowały się przystąpić do egzaminu notarialnego w latach 2016-2020, dane informujące o liczbie osób, które otrzymały pozytywny wynik z egzaminu notarialnego w latach 2018-2020, a na ich podstawie zostanie obliczony odsetek osób, którym udało się uzyskać pozytywny wynik w latach 2018-2020 ze wskazanego egzaminu. Rzeczone dane zostały przedstawione na trzech poniższych grafach oraz w dwóch tabelach.

Liczba osób przystępujących do egzaminu notarialnego w latach 2016-2020

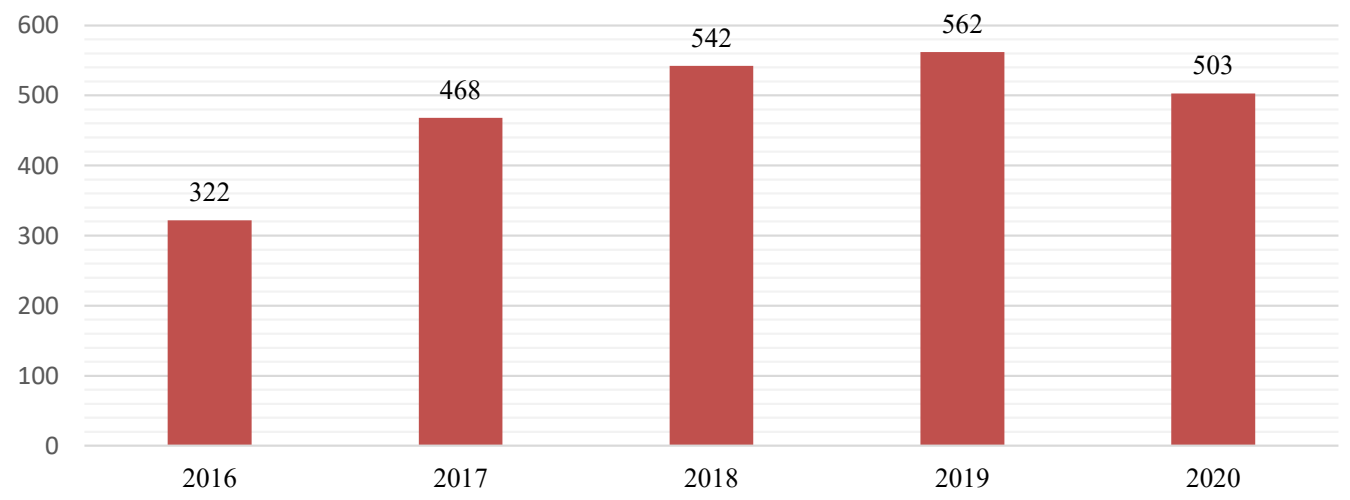

Wykres 1. Liczba osób przystępujących do egzaminu notarialnego w latach 2016-2020

Źródło: Źródło własne na podstawie zestawienia ze strony Ministerstwa Sprawiedliwości, https://www.arch.ms.gov.pl/pl/egzaminy-prawnicze/zawodowe-egzaminy-prawnicze/ogloszenia-

i-komunikaty, https://www.gov.pl/web/sprawiedliwosc/wyniki-egzaminu-notarialnego oraz wyników opublikowanych przez Izbę Notarialną w Gdańsku, Katowicach, Krakowie, Poznaniu,

Warszawie i Wrocławiu w 2020 roku

Tabela 1

Liczba osób, które uzyskały pozytywny wynik z egzaminu notarialnego w poszczególnych izbach notarialnych w Polsce w latach 2018 i 2019

\begin{tabular}{|c|l|c|c|}
\hline \multicolumn{1}{|c|}{2018} & $\begin{array}{c}\text { Liczba osób, które otrzymały } \\
\text { pozytywny wynik w 2018 roku }\end{array}$ & $\begin{array}{c}\text { Liczba osób, które otrzymały } \\
\text { pozytywny wynik w 2019 roku }\end{array}$ \\
\hline 1 & Gdańsk & 39 & 38 \\
\hline 2 & Katowice & 11 & 23 \\
\hline 3 & Kraków & 16 & 54 \\
\hline 4 & Poznań & 46 & 54 \\
\hline 5 & Warszawa & 21 & 81 \\
\hline 6 & Wrocław & 49 & 36 \\
\hline & Ogółem & 182 & 286 \\
\hline
\end{tabular}

Źródło: Źródło własne na podstawie danych zawartych na podstawie zestawienia ze strony Ministerstwa Sprawiedliwości, https://www.arch.ms.gov.pl/pl/egzaminy-prawnicze/zawodoweegzaminy-prawnicze/ogloszenia-i-komunikaty, https:/www.gov.pl/web/sprawiedliwosc/wynikiegzaminu-notarialnego oraz własnych obliczeń pomocniczych 
Tabela 2

Liczba osób przystępujących do egzaminu zawodowego, zestawienie liczby osób, które otrzymały pozytywny i negatywny wynik oraz procent zdawalności egzaminu notarialnego w poszczególnych izbach notarialnych w Polsce w 2020 roku

\begin{tabular}{|c|l|c|c|c|c|}
\hline & $\begin{array}{c}\text { Izba } \\
\text { notarialna }\end{array}$ & $\begin{array}{c}\text { Liczba osób } \\
\text { przystępujących } \\
\text { do egzaminu } \\
\text { notarialnego }\end{array}$ & $\begin{array}{c}\text { Liczba osób, } \\
\text { które uzyskaly } \\
\text { pozytywny wynik } \\
\text { z egzaminu } \\
\text { notarialnego }\end{array}$ & $\begin{array}{c}\text { Liczba osób, } \\
\text { które uzyskały } \\
\text { negatywny wynik } \\
\text { z egzaminu } \\
\text { notarialnego }\end{array}$ & $\begin{array}{c}\text { Procent } \\
\text { zdawalności }\end{array}$ \\
\hline 1 & Gdańsk & 75 & 34 & 41 & $45,33 \%$ \\
\hline 2 & Katowice & 47 & 14 & 33 & $29,79 \%$ \\
\hline 3 & Kraków & 65 & 28 & 37 & $43,08 \%$ \\
\hline 4 & Poznań & 120 & 29 & 91 & $24,17 \%$ \\
\hline 5 & Warszawa & 144 & 46 & 98 & $31,94 \%$ \\
\hline 6 & Wrocław & 52 & 17 & 35 & $32,69 \%$ \\
\hline & Ogółem & 503 & 168 & 335 & $33,40 \%$ \\
\hline
\end{tabular}

Źródło: Źródło własne opracowane na podstawie wyników opublikowanych przez Izbę Notarialną w Gdańsku, Katowicach, Krakowie, Poznaniu, Warszawie i Wrocławiu w 2020 roku

Zdawalność egzaminu notarialnego w latach 2018-2020 (przed i po uwzględnieniu odwołań)

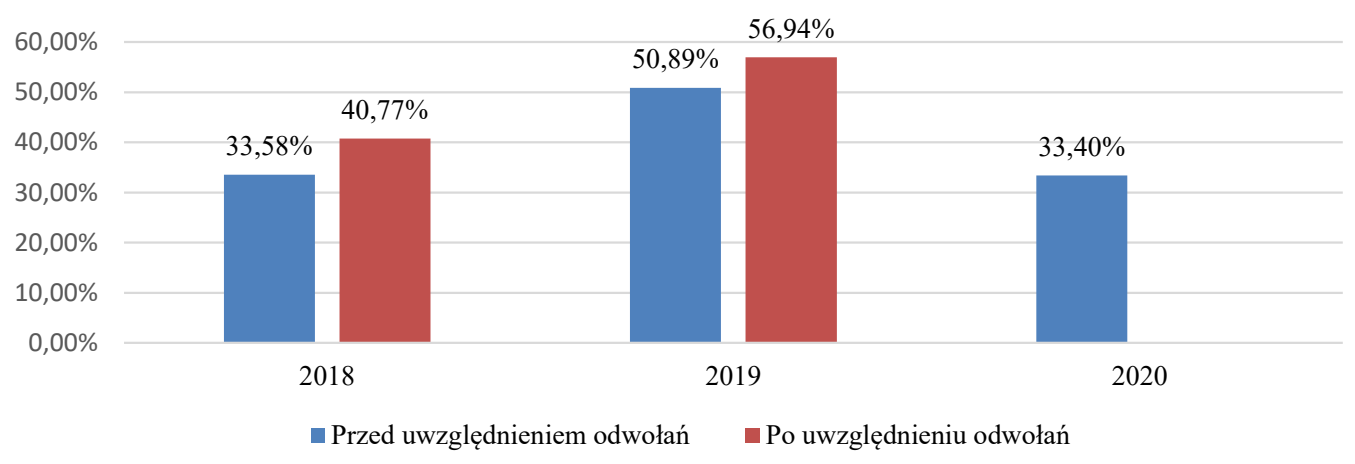

\section{Wykres 2. Zdawalność egzaminu notarialnego w latach 2018-2020 (przed i po uwzględnieniu odwołań)}

Źródło: Źródło własne na podstawie zestawienia ze strony Ministerstwa Sprawiedliwości, https://www.arch.ms.gov.pl/pl/egzaminy-prawnicze/zawodowe-egzaminy-prawnicze/ogloszenia-

i-komunikaty, https://www.gov.pl/web/sprawiedliwosc/wyniki-egzaminu-notarialnego oraz wyników opublikowanych przez Izbę Notarialną w Gdańsku, Katowicach, Krakowie, Poznaniu,

Warszawie i Wrocławiu w 2020 roku

Przechodząc do analizy przedstawionych powyżej danych należy wyszczególnić kilka następujących implikacji.

Po pierwsze, w przeciwieństwie do egzaminu wstępnego na aplikację notarialną, w przypadku egzaminu notarialnego, pomiędzy 2019 a 2020 rokiem, nastąpił spadek liczby osób przystępujących do rzeczonego egzaminu. Zjawisko to jest tym bardziej nieoczekiwane, że 
począwszy od 2016 roku mieliśmy do czynienia z ciągłym wzrostem liczby osób, które decydowały się przystąpić do egzaminu notarialnego. Ponadto, uwzględniając fakt, iż okres trwania aplikacji notarialnej trwa 3 lata i 6 miesięcy (Art. 71 \& 8 ustawy z dnia 14 lutego 1991 r.), można założyć, że przeważający odsetek osób zdających egzamin notarialny w 2020 roku, przystępowało do egzaminu wstępnego na aplikację notarialną w 2016 roku. Jest to o tyle ważna do odnotowania zależność, gdyż wówczas łączna liczba osób przystępujących do egzaminu wstępnego na aplikację notarialną była najwyższa. W związku z powyższym zasadnym pozostaje postawienie hipotezy, iż epidemia COVID-19 mogła być jednym z czynników, który negatywnie wpłynął na możliwość dostępu do rzeczonego prawniczego egzaminu zawodowego.

Po drugie zdawalność egzaminu notarialnego charakteryzuje się wysoką fluktuacją wyników i jest niezwykle niska. Biorąc pod uwagę wyłącznie informacje odnoszące się do 2020 roku, zdawalność egzaminu wyniosła zaledwie 33,40\%. Najnowsze dane dotyczące bieżącego roku nie uwzględniają w prawdzie odwołań, dlatego też wskaźnik zdawalności może okazać się nieznacznie wyższy. Niemniej jednak, już w tym momencie można stwierdzić, że zdawalność wśród osób przystępujących do egzaminu w 2020 roku okaże się prawdopodobnie najniższa w ciągu trzech ostatnich lat. Ponadto negatywnym zjawiskiem pozostaje niewątpliwie znaczne zróżnicowanie wyników w poszczególnych izbach notarialnych. Podczas gdy zdawalność egzaminu notarialnego w Gdańsku wyniosła 45,33\% (wynik wyższy od średniej krajowej o 11,93\%), w Poznaniu wynik ten wynosił zaledwie 24,17\% (wynik niższy od średniej krajowej o 9,23\%). Różnica między wartościami skrajnymi to aż 21,16\%.

Po trzecie należy zwrócić uwagę na różnicę zachodzącą pomiędzy zdawalnością egzaminu notarialnego przed i po uwzględnieniu odwołań. W wyniku rzeczonej procedury liczba pozytywnych wyników z egzaminu w 2018 roku zwiększyła się odpowiednio o 7,19\%, natomiast w 2019 roku o 6,05\%. Wysoka rozbieżność zachodząca pomiędzy wynikami jest bez wątpienia zjawiskiem negatywnym. Świadczyć może o niedoskonałym systemie sprawdzania prac. Ponadto, rzeczone zjawisko zaburza obraz faktycznej zdawalności egzaminów notarialnych, jednocześnie wprowadzając powszechny stan dezinformacji wśród wszelkich osób zainteresowanych wskazanym tematem.

Reasumując, zasadnym pozostaje postawienie hipotezy mówiącej o tym, że epidemia COVID-19 była jednym z kilku czynników, który mógł mieć wpływ na dostęp do egzaminów notarialnych. Należy jednak wskazać, że wpływ ten nie miał jednostronnego charakteru. W przypadku egzaminów notarialnych wpływ ten był negatywny, co jest zauważalne przede wszystkim poprzez nagły spadek liczby osób, które zdecydowały się przystąpić do rzeczonego egzaminu. Przechodząc do analizy egzaminu notarialnego zauważyć należy, że spadek liczby osób, które uzyskały pozytywny wynik z rzeczonego egzaminu prawdopodobnie nie pozostawał w związku z epidemią COVID-19. Tak jak wskazano w powyższej pracy, zdawalność egzaminu notarialnego charakteryzuje się wysokim zróżnicowaniem wyników w różnych latach. Czynnikami, które mają decydujący wpływ na osiągane przez przystępujących, pozostają przede wszystkim trudność pytań egzaminacyjnych, czy też stopień przygotowania zdających osób.

Generalnie należy jednak wskazać, iż do wskazanego stanu rzeczy mogły przyczynić się również inne czynniki, w tym ograniczenia pandemiczne. Dlatego też nieodzowna powinna być pogłębiona analiza dotycząca rzeczonego tematu, która wykraczać będzie daleko poza czynniki o charakterze ekonomicznym i prawnym. Jednakże, kardynalnym wyznacznikiem dla tak pogłębionej egzegezy winno być założenie, wynikające wprost z dyrektywy zawartej w art. 17 ust. 1 Konstytucji RP, przewidujące możliwość powołania dla osób, wykonujących „zawody zaufania publicznego”, struktur samorządu zawodowego i nadanie im stosownych 
uprawnień. Oznacza to, iż wymienione zawody winny występować jako korporacje publicznoprawne, tj. przymusowe zrzeszenia, wyposażone w pewnego rodzaju władztwo publiczne wobec swych członków i takowe władztwo dla transparentności wykonywania owych profesji winno być w jeszcze większym stopniu scedowane na korporacje zawodowe w szczególności w zakresie kształcenia i dopuszczania do zawodu notariusza (Wiatrowski, Wiatrowski, 2020).

\section{Bibliografia}

Art. 71 \& 8 ustawy z dnia 14 lutego 1991 r. Prawo o Notariacie (Dz. U. 1991 Nr 22 poz. 91) Encyklopedia Powszechna PWN, pod red. S. Puchaty, Warszawa 1974, tom III, s. 305.

Konstytucja Rzeczpospolitej Polskiej z dnia 2 kwietnia 1997 (Dz.U. z 1997 nr. 78 poz. 483) z póź. zmianami.

Sarnecki P., Komentarz do art. 17, [w:] Konstytucja Rzeczypospolitej Polskiej. Komentarz, L. Garlicki (red.), t. IV, Warszawa 2005, s 2.

Ustawa z dn. 14 lutego 1991 r. Prawo o notariacie (Dz. U. Nr 22 poz. 91 z późn. zm.)

Wiatrowski J., Nowicka A. „Egzegeza przyczyn skokowego przyrostu podmiotów świadczacych profesjonalna pomoc prawna” Scientific Journal of Polonia University, 2019, 32.1: 110-115.

Wiatrowski J., Wiatrowski K., Rozdziat w Monografii Tom II pod tytułem „, Problemy Zdrowia Publicznego". Tytuł rozdziału - Lekarz jako zawód zaufania publicznego- Wydawnictwo Uniwersytetu Humanistyczno-Przyrodniczego im. Jana Długosza w Częstochowie 2020 r. s. 79.

Wiatrowski K., Wiatrowski J., Wanot B. „Uwarunkowania i ekonomiczno-prawny charakter wykonywania prawniczych profesji zaufania publicznego w konfrontacji z zawodem lekarza" Częstochowa 2020 r. Wydawnictwo Uniwersytetu Humanistyczno-Przyrodniczego w Częstochowie s. 11. 